\title{
A imagem dos Tribunais de Contas subnacionais'
}

Rogério Bastos Arantes, Fernando Luiz, Abrucio e Marco Antonio Carvalho Teixeira

\section{Introdução}

A investigação sobre a imagem das instituições políticas junto ao eleitorado e às elites sociais é uma ferramenta fundamental para aprimorar a democracia e melhorar o desempenho do Estado. Com pesquisas dessa natureza, é possível descobrir a percepção externa de lacunas e erros de tais instituições, alguns deles imperceptíveis para os seus componentes, bem como coletar sugestões para o seu aperfeiçoamento. A importância dessas sondagens torna-se maior quando a instituição em questão é pouco conhecida pela sociedade e existe, ademais, uma visão difusa que a qualifica de forma negativa. Este artigo retrata um caso que se encaixa nessa situação: os Tribunais de Contas (TCs) subnacionais.

Esta pesquisa originou-se de projeto desenvolvido pelo Ministério do Planejamento, intitulado Programa de Modernização do Sistema de Controle Externo dos Estados e do Distrito Federal (Promoex)². Sua ela boração ocorreu em parceria com os dirigentes e técnicos dos 33 TCs subnacionais e conta com 
o apoio financeiro do Banco Interamericano de Desenvolvimento (BID). O objetivo do Promoex é modernizar o controle externo dos governos estaduais e municipais, reformulando a gestão dos TCs, em prol de sua maior eficiência, efetividade, transparência e accountability.

Numa primeira etapa, a Fundação Instituto de Administração (FIA) da Universidade de São Paulo (USP) realizou ampla radiografia dos Tribunais de Contas subnacionais (2002), cujos dados deram importantes subsídios para a formulação de projetos de mudança dos TCs; não captaram, porém, uma dimensão essencial em qualquer processo de reforma institucional: a percepção dos atores estratégicos, em particular os externos à instituição em questão.

Foi essa constatação que levou à elaboração de um survey de elites sociais e institucionais, que, de um modo ou de outro, são afetadas pelos TCs e podem, ao mesmo tempo, exercer uma corrente de opinião decisiva contra eles ou a favor deles, influenciando, assim, sua capacidade e legitimidade de exercer a autoridade de controlador de contas públicas.

Cabe esclarecer, inicialmente, o uso dos termos "elites sociais e institucionais", bem como do conceito de "atores estratégicos". Utilizamos o termo "elites" com o significado de "lideranças" que desempenham papel relevante na sociedade e/ou no Estado e cuja identificação pode se dar por critérios de posição formal numa dada hierarquia ou por reputação e influência perante o cenário público. Metodologicamente, essa acepção é defendida por dois dos maiores especialistas em pesquisas de opinião no Brasil, os cientistas políticos Bolívar Lamounier e Amaury de Souza. Dizem eles:

"Que é 'elite'? O termo presta-se, como é sabido, a um uso polêmico ou político (...). O conceito é utilizado apenas no sentido corrente nas ciências sociais - praticamente sinônimo de "lideranças", como coletivo genérico. Toda sociedade é formada por distintas hierarquias, cada uma delas baseada em diferentes recursos de influência ou poder. 'Elite' são as pessoas que ocupam o ápice dessas diferentes hierarquias e conseqüentemente exercem, ou podem vir a exercer, importante influência nas decisões governamentais e nos destinos da sociedade. No sentido acima, fazem parte da elite tanto os grandes empresários como os médios ou pequenos reconhecidos por sua liderança; líderes sindicais; políticos; altos administradores públicos; oficiais superiores das Forças Armadas; intelectuais; profissionais liberais; jornalistas e líderes associativos. A seleção dos entrevistáveis, como em geral ocorre em pesquisas sobre elites, base[ia]-se tanto em critérios de posição (ocupação de importantes cargos) como de reputação (ser considerado uma pessoa influente por outros membros da elite ou por pesquisadores experientes)" (Lamounier; SouzA, 1992: 9).

Já o termo "atores estratégicos" vincula-se à forma de selecionar as "elites" a serem entrevistadas, a partir do grau de importância que tais grupos têm em relação aos Tribunais de Contas subnacionais. Nesse sentido, "elites" e "ator es estratégicos" não são noções sinônimas, mas sim, complementares, tendo em vista os objetivos da pesquisa: combinar os dois critérios posição/capacidade de liderança e relação estratégica do ator com os TCs -, de modo a produzir diagnóstico e perspectivas de reforma dessas instituições. Assim, se a opção fosse apenas pelo critério de "elites", 
a amostra incluiria possivelmente empresários, lideranças sindicais e a Igreja. Dada a dimensão "estratégica" da relação de alguns organismos da sociedade civil com os TCs, entretanto, privile giamos estes - conselhos regionais de contabilidade, administração e engenharia, entre outros, como veremos no desenho da amostra - e dispensamos outros que correspondem ao critério de "elites", mas que seriam pouco relevantes para os objetivos deste trabalho. Ressalte-se, aliáş que o adjetivo "social" é utilizado no texto apenas para caracterizar atores não-estatais da amostra (imprensa, acadêmicos, ONGs, a Ordem dos Advogados do Brasil e os três conselhos regionais) e não tem a pretensão de designar uma representação geral da sociedade brasileira.

Uma última observação metodológica: a seleção dos atores estratégicos foi feita em diálogo com os técnicos dos Tribunais de Contas subnacionais que participam do Promoex, dando maior legitimidade para a amostra. Ao mesmo tempo, tivemos a palavra final sobre o desenho da pesquisa, garantindo com isso a necessária isenção científica.

O presente texto pretende resumir as principais conclusões desta pesquisa sobre a imagem dos Tribunais de Contas subnacionais, de modo que não se trata de uma avaliação sistemática de suas políticas, mas sim, de um retrato construído pela percepção de elites sociais e institucionais, enquadradas como atores estratégicos em relação a esta instituição de controle.

\section{O universo pesquisado e os instrumentos de investigação}

A reforma de qualquer instituição pública, em ambiente democrático, depende do apoio de atores sociais estratégicos. No momento em que os TCs subnacionais decidiram passar por ampla reformulação, eles necessariamente precisariam saber a opinião que a sociedade e os outros poderes tinham dele. Mais do que isso, duas hipóteses implícitas incomodavam os principais agentes desse processo reformista: haveria um descontentamento difuso em relação ao seu desempenho e suas ações e funções seriam pouco conhecidas, inclusive por instituições e grupos com maior contato com os TCs.

Diante disso, foi montado um survey de elites institucionais e sociais, composto por cinco grandes setores, subdivididos em categorias específicas. Essa amostra procurou representar a diversidade de atores públicos e sociais que, em cada estado, mantêm com os TCs alguma relação institucional e política ou guardam algum tipo de expectativa quanto ao bom desempenho de suas funções, como é caso de setores organizados da sociedade civil.

Foram selecionados, então, atores vinculados ao Legislativo, ao Executivo, ao Judiciário, ao Ministério Público e à sociedade civil organizada, levando-se em conta que, em alguns casos, os TCs tinham como função fiscalizar os estados e municípios, enquanto noutros, somente os municípios, e em dois deles, os Tribunais de Contas dos Municípios de São Paulo e do Rio de Janeiro, a fiscalização envolve apenas o poder público de tais capitais. Isso criou algumas variações na amostra, sem, no entanto, modificar profundamente o conjunto de entrevistados. No total, foram escolhidas 919 pessoas, tal como relatado no Quadro 1.

Houve enorme dificuldade em conseguir entrevistar todos os selecionados, por conta do tempo de trabalho - cerca de três meses -, da abrangência territorial da pesquisa - todos os estados da Federação - e da reticência de alguns grupos em dar entrevistas e, principalmente, emitir opiniões sobre uma instituição pública como os Tribunais de Contas. O Judiciário e o 
Quadro 1: Amostra dos atores públicos e sociais

\begin{tabular}{|c|c|c|}
\hline Setores & Subsetores & $\begin{array}{l}\text { Número de } \\
\text { entrevistas }\end{array}$ \\
\hline \multirow[t]{8}{*}{ Legislativo } & Presidente da Assembléia Legislativa & 1 \\
\hline & $\begin{array}{l}\text { Dep. Estadual (governista) da Comissão de } \\
\text { Orçamento }\end{array}$ & 1 \\
\hline & $\begin{array}{l}\text { Dep. Estadual (oposicionista) da Comissão } \\
\text { de Orçamento }\end{array}$ & 1 \\
\hline & $\begin{array}{l}\text { Dep. Estadual (governista) da Comissão de } \\
\text { Orçamento }\end{array}$ & 1 \\
\hline & $\begin{array}{l}\text { Dep. Estadual (oposicionista) da Comissão } \\
\text { de Orçamento }\end{array}$ & 1 \\
\hline & Vereadores da capital & $2(4) *$ \\
\hline & Vereadores de cidade média & 1 \\
\hline & Vereadores de cidade pequena & 1 \\
\hline \multirow[t]{6}{*}{ Executivo } & Gestores, técnicos estaduais & 4 \\
\hline & Gestores, técnicos do município da capital & $2(4) *$ \\
\hline & Gestores, técnicos de uma cidade média & 1 \\
\hline & Gestores, técnicos de uma cidade pequena & 1 \\
\hline & Controle interno - governo estadual & 3 \\
\hline & Controle interno - município da capital & $1(2) *$ \\
\hline \multirow[t]{2}{*}{ Judiciário } & Desembargadores do Tribunal de Justiça & 2 \\
\hline & Juiz do TRE & 1 \\
\hline \multirow[t]{2}{*}{ Ministério Público } & Procurador-Geral de Justiça & 1 \\
\hline & Promotores de Justiça da Cidadania & 2 \\
\hline \multirow[t]{7}{*}{ Sociedade civil } & Imprensa & 1 \\
\hline & Universidade/acadêmicos & 1 \\
\hline & $\mathrm{OAB}-$ seccional & 1 \\
\hline & ONG & 1 \\
\hline & Conselho de Engenharia & 1 \\
\hline & Conselho de Contabilidade & 1 \\
\hline & Conselho de Administração & 1 \\
\hline $\begin{array}{l}\text { Total de entrevistas por } \\
\text { estado (menos DF, SP e RJ) }\end{array}$ & & 34 \\
\hline $\begin{array}{l}\text { Total de entrevistas, conside- } \\
\text { rando os } 26 \text { estados e o } \\
\text { Distrito Federal }\end{array}$ & & $919 * *$ \\
\hline
\end{tabular}

* Os números entre parêntesis dizem respeito às quotas adotadas nesse setor, nos Estados de São Paulo e Rio de Janeiro.

** O total reflete a soma de entrevistas por estado, descontadas nove entrevistas de âmbito municipal no Distrito Federal (vereadores, gestores e controle interno) e considerado o acréscimo nas quotas municipais de São Paulo e Rio de Janeiro, indicadas acima. 
Ministério Público foram os mais arredios, ao passo que o Executivo e a sociedade foram os que mais aderiram à sondagem.

O resultado líquido foi um número menor de entrevistas, 644, ou seja, 70,1\% do total. Independentemente disso, consideramos que o contingente atingido foi suficiente para compor amostra de extensão nacional e aferir conclusões que, como dito no início, estavam mais preocupadas em construir uma imagem externa dos TCs do que avaliar estritamente o seu desempenho. Trata-se de número compatível com pesquisas de opinião de mesma escala realizadas no Brasil e no mundo. Estas últimas, aliás, trabalham com algo em torno de 2000 entrevistas para representar um universo de dezenas de milhões de pessoas, enquanto este survey recorreu a 644 entrevistas para representar alguns poucos milhares de lideranças e atores estratégicos.

É importante frisar, de outra parte, que a amostra da pesquisa não teve a intenção de fazer uma representação estatística de cada setor e, por isso, o número de entrevistados não pode ser visto isoladamente. Quanto ao número de entrevistas por estado, lembramos que o universo selecionado tinha como meta produzir um retrato em escala nacional - não cabe, assim, uma interpretação de cada estado individualmente. De qualquer forma, vale mais uma vez citar Bolívar Lamounier e Amaury de Souza para referendar metodologicamente nossa posição:

“Qual deveria ser o número de entrevistados em diferentes setores? Por exemplo, quantos empresários, quantos políticos, quantos intelectuais? Não existe possibilidade de uma resposta exata a esta questão, visto que não existem parâmetros precisos para a seleção estatisticamente rigorosa de uma amostra. O importante, num trabalho [de survey de elites nacional], é que o conjunto finalmente entrevistado seja plausivel como representação das lideranças destacadas do País” (LAMOUnier; Souza, 1992:10).

Ressalte-se que o texto dos autores citados se referia a uma pesquisa que continha oito setores e na qual foram entrevistadas 450 lideranças, números que, cotejados aos utilizados pelo presente trabalho, nos dão-nos mais segurança para as inferências e conclusões aqui expostas.

Os questionários aplicados aos atores estratégicos dos Tribunais de Contas subnacionais continham questões gerais para todos os grupos e algumas específicas. Em sua grande maioria, as perguntas eram fechadas e pediam algum tipo de avaliação com gradação de intensidade. Em poucas delas e, sobretudo no final do questionário, admitiu-se abordagem mais aberta, com a possibilidade de respostas mais longas e diversificadas. Pretendia-se, com esse instrumento, espelhar, de forma mais qualitativa, a imagem dos TCs.

Cinco grandes linhas nortearam o questionário: aspectos referentes ao relacionamento dos TCs com o campo ao qual estava vinculado o entrevistado, à gestão e eficiência dos tribunais, à sua transparência/ accountability, uma avaliação mais geral de seu desempenho e sugestões de reformulação institucional. Analisaremos, a seguir, na forma breve que permite este artigo, alguns dos resultados e conclusões obtidos.

O Tribunal de Contas e seu relacionamento com as instituições e a sociedade: nível de conhecimento e avaliação da importância institucional

Os resultados do survey evidenciaram que a amostra geral de entrevistados tinha um grau de conhecimento bastante 
significativo das atividades do TC. $\mathrm{Na}$ média dos setores, mais de $1 / 3$ da amostra (38\%) afirmou ter nível elevado de conhecimento das atividades do TC (somando "muito alto" e "alto") e quase a metade $(46 \%)$ tem, pelo menos, grau médio de conhecimento. Esses dados qualificam a amostra como apta a tecer considerações sobre as atividades desempenhadas pelos TCs subnacionais. Na média, apenas 13,8\% afirmaram ter reduzido conhecimento da instituição e irrisório $1,5 \%$ afirmou desconhecer completamente o trabalho dela.

Como era de se esperar, o maior percentual de desconhecimento (4,2\%) ocorreu na sociedade civil, assim mesmo num valor muito baixo, que não chega a comprometer a representatividade desse setor na amostra e, mais do que isso, vai contra uma das hipóteses iniciais: a de que os setores sociais majoritariamente ignoram as funções dos TCs subnacionais. Se somarmos as respostas "muito alto" e "alto", os maiores percentuais de elevado conhecimento encontram-se entre o Controle Interno (49\%) e o Ministério Público (46\%), vindo a seguir o Judiciário $(32,5 \%)$, depois a sociedade civil $(28,9 \%)$ e finalmente os gestores e técnicos do Executivo $(26,8 \%)$.

Com relação à freqüência com a qual os entrevistados utilizam determinadas informações produzidas pelos Tribunais de Contas subnacionais, constatou-se que a informação mais freqüientemente utilizada é a "apreciação das contas do chefe do Poder Executivo" (26,12\%), seguida de perto pelo "julgamento das contas dos ordenadores de despesa" (21,68\%). Certamente, por sua maior especificidade, as informações menos utilizadas dizem respeito aos itens 9 e 10 da referida questão (acompanhamento das contas do Judiciário e do Ministério Público, com respectivamente
$55,1 \%$ e $54, \%$ de respostas "nunca", na média dos setores).

Observando-se os setores específicos, o Legislativo é aquele que mais se destaca por usar freqüentemente as informações produzidas pelo TC (29\%, na média dos itens), seguido pelo Ministério Público (17\%, na média dos itens). Gestores e técnicos do Executivo, membros do Judiciário e da sociedade civil recorrem menos às informações produzidas pelos TCs e equiparam-se em torno de $11 \%$, na média dos itens.

No caso dos setores públicos, o item mais importante da lista diz respeito à apreciação e ao acompanhamento de suas próprias contas. Em segundo lugar, no caso do Legislativo, vem o interesse pela "apreciação das contas do chefe do Poder Executivo". No caso dos gestores e técnicos do Executivo, dois itens aparecem empatados em segundo lugar: "Julgamento das contas dos ordenadores de despesa" e "Relatórios de auditorias". Entre os juízes, o segundo maior interesse, depois de suas próprias contas, recai sobre a "apreciação de a posentadorias, reformas e pensões". No caso do Ministério Público, é interessante notar que os entrevistados fazem uso mais abrangente das informações produzidas pelos TCs. Cerca de $1 / 4$ dos membros do MP afirmou fazer uso freqüente de, pelo menos, 5 dos 11 itens listados na tabela. Quanto à sociedade civil, a "apreciação das contas do chefe do Poder Executivo" empata em primeiro lugar com o uso freqüente de informações relativas à "apreciação de denúncias e representações".

Os entrevistados que fazem uso das informações produzidas pelo TC foram instados a avaliar também a qualidade e a utilidade delas. A avaliação positiva (soma de "ótimo" e "bom") daqueles que chegaram a utilizar alguma das 11 
informações listadas chegou a 79\%, na média dos setores. Embora sejam os que menos utilizam informações produzidas pelos TCs, os juízes são os que melhor as avaliam (87\%), um pouco acima da avaliação dos parlamentares - com 85\% das alternativas "ótima" ou "boa" somadas -, seguidos, mais abaixo, pelo Ministério Público (78\%) e pela sociedade civil (74\%). Os gestores e técnicos do Executivo foram os que fizeram a avaliação menos positiva, com $70 \%$ de aprovação e $30 \%$ de avaliação negativa (quando somadas as alternativas "inadequada" e "péssima").

Com resultados similares à questão anterior, 78\% dos entrevistados que utilizam informações produzidas pelo TC consideraram-nas "úteis" ou "muito úteis". A seqüência da avaliação dos setores quanto à utilidade mudou pouco em relação à seqüência da qualidade: em primeiro, $86 \%$ dos juízes que usam as informações consideram-nas "muito úteis" ou "úteis", seguidos de perto pelos parlamentares com $83 \%$, vindo, a seguir, a sociedade civil (77\%) e o Ministério Público (75\%). Mais uma vez, foram os gestores e técnicos do Executivo que deram menor grau de aprovação à utilidade das informações (68\% de "muito útil" ou "útil”), se comparados aos demais atores.

A pesquisa procurou analisar também a relação mais específica de alguns setores estabelecidos na amostra com os TCs subnacionais. Desses dados, o que mais chamou atenção foram os resultados referentes aos atores do Executivo gestores e integrantes do controle interno -, Ministério Público e Judiciário.

É preocupante notar que uma parte significativa dos gestores e técnicos do Executivo nunca ou raramente utiliza os serviços dos TCs subnacionais $(44,1 \%)$ e $33 \%$ só o fazem eventualmente, diante de $22,1 \%$ que alegam utilizar sempre ou freqüentemente o apoio da instituição controladora. Ademais, esses mesmos atores, objetos por excelência da fiscalização dos tribunais, alegam terem sido pouco fiscalizados pelos TCs, afirmação em si muito preocupante para a accountability democrática do sistema político brasileiro. No que diz respeito à legalidade, 36,9\% afirmaram que nunca sofreram qualquer tipo de fiscalização e $23,8 \%$ teriam sido fiscalizados, no máximo, duas vezes. No que se refere ao controle por resultados (em verdade, uma atividade ainda pouco desenvolvida pelos TCs), 51,2\% deles afirmaram não ter passado por esse tipo de fiscalização, diante de um total de $28 \%$ que já passaram por ela duas vezes ou mais. Note-se que 22,8\% dos entrevistados nem sequer responderam à pergunta.

Apesar de pouco enfatizar o papel fiscalizador dos Tribunais de Contas, a maior parte dos gestores e técnicos do Executivo que se prontificaram a avaliar a relação que tiveram com os auditores do TCs considerou-a ótima ou boa (47\%), ao passo que $10,7 \%$ consideraram tal relacionamento ruim ou péssimo. Portanto, não se trata, nesse caso, de problema de qualidade técnica da ação desses tribunais, mas de maior efetividade desses órgãos no controle do Executivo. Nessa mesma linha de raciocínio, um número muito expressivo de gestores estaduais e municipais $(62,5 \%)$ disse que não se criaram formas de cooperação entre o Executivo e Tribunal de Contas, enquanto 26,8\% afirmaram que sim e $10,7 \%$ não responderam.

Uma pista para pensar essa problemática foi dada pela resposta referente ao papel dos tribunais como agentes da Lei de Responsabilidade Fiscal (LRF): 48,8\% dos gestores e técnicos do Executivo disseram que a ação dos TCs teve impacto no cumprimento da LRF, 42,9\% disseram 
que não e $8,3 \%$ não responderam. Trocando em miúdos, quando existe uma ação mais forte e programada dos TCs, ancorada em lei com grande legitimidade social, suas atividades tornam-se importantes para o Executivo. Esse mesmo ambiente institucional tem de ser constituído em outras frentes de atuação dos TCs subnacionais, para que se reforcem sua legitimidade e autoridade junto aos governos estaduais e municipais, a fim de tornar mais compreensível e efetivo o seu papel institucional.

Com relação aos integrantes do Controle Interno, 66,2\% dos entrevistados consideram que a relação com o Tribunal de Contas é ótima ou boa, enquanto 26,5\% consideram-na ruim. Tais dados demonstram que, nesse setor, também do Executivo, a receptividade em relação ao papel desempenhado pelo TC é maior do que o verificado junto aos gestores e técnicos e, mesmo quando tais atores avaliam negativamente o relacionamento, a principal razão aventada é a má estruturação administrativa do próprio Controle Interno.

O tema da parceria institucional, com vistas a favorecer o controle externo da administração pública foi abordado pelos entrevistados do Judiciário e do Ministério Público. No caso dos magistrados, 55,8\% deles mostraram-se favoráveis a essa hipótese e 41,9\% parecem resistir à idéia. $\mathrm{O}$ dado que mais chama a atenção vem do Ministério Público. Entre seus membros, a receptividade em relação à parceria institucional foi impressionante: nada menos do que 90,7\% colocaram-se a favor de algum tipo de ação conjunta entre o Ministério Público e o TC e apenas 7,4\% não apóiam a idéia. Ao mencionar sugestões concretas nesse sentido, um grande número de promotores e procuradores de justiça demonstrou forte interesse no corpo técnico e no aparato material dos
TCs e propuseram várias formas de cooperação entre as duas instituições. Como afirmou um dos entrevistados,

"O Tribunal de Contas é um órgão técnico e o MP tem o poder coercitivo, através da ação civil pública de improbidade. Os órgãos, agindo de forma independente (sem interação), não chegam a lugar nenhum. Se unirem seus pontos fortes, certamente haveria diminuição da corrupção".

A maior receptividade do Ministério Público em relação à idéia de aproximação com os TCs pode ser confirmada também pela opinião dos membros da instituição sobre os relatórios produzidos pelos TCs e encaminhados à ela, para que esta possa instruir as ações penais: 59,3\% dos membros do MP consideram que esses relatórios têm a fundamentação técnica adequada, enquanto $18,5 \%$ afirmam que não e $22,2 \%$ não responderam a pergunta. Entre os juízes, o percentual de aprovação dos relatórios do TC aplicados a ações penais foi de apenas $39,5 \%$. Quatorze por cento afirmaram que os relatórios possuíam fundamentação técnica adequada e uma maioria de 44,2\% não respondeu a pergunta.

Num primeiro balanço, os dados revelam, em primeiro lugar, que os setores técnicos ligados ao Executivo estão na faixa dos que usam com menor freqüência as informações dos TCs subnacionais e, ademais, avaliam mal a utilidade dos dados e tarefas vinculados a esses tribunais. Poderse-ia argumentar, intuitivamente, que, como se trata do Poder mais investigado pelos tribunais, haveria maior probabilidade de avaliação negativa. Só que a visão negativa sobre o grau de utilidade das informações pode revelar algo pior: uma dificuldade enorme de comunicação, o que, ao fim e ao cabo, tende a prejudicar o processo de controle. Outra 
constatação importante refere-se ao papel de legislações, como a Lei de Responsabilidade Fiscal, para ativar e legitimar a sua atividade fiscalizadora. Mecanismos similares a esses relacionados à LRF poderiam ativar outras de suas atribuições, como a de controle e avaliação dos resultados das políticas públicas, a partir de legislação que obrigasse a criação de contratualização entre o Executivo e os Tribunais de Contas em torno de metas e formas de aferição de desempenho do governo.

Por fim, a extrema importância que os membros do Ministério Público deram à possibilidade de se firmarem parcerias com os TCs pode ser um novo caminho de atuação institucional e construção de accountability, numa linha pouco explorada no sistema político brasileiro. Contudo, cabe ressaltar que o MP tem ampliado suas atribuições desde a Constituição de 1988 e, muitas vezes, atropela ou toma para si as funções de outras instituições, em vez de simplesmente dividir tarefas com elas, como revelam alguns estudos recentes (Arantes, 2002; Strauss, 2005). Numa situação em que os TCs precisam fortalecer sua legitimidade e autoridade, a cooperação institucional pode ser positiva, contanto que fiquem bem definidas as funções de cada qual.

\section{Qualidade, capacidades institu- cionais e mérito das decisões dos Tribunais de Conta}

A qualidade da gestão dos Tribunais de Contas subnacionais e a legitimidade de suas decisões constituíram dois temas fundamentais para a pesquisa. No primeiro bloco, destaca-se inicialmente a avaliação dos TCs, no que diz respeito à facilidade de acesso, à qualidade e ao tempo de resposta de serviços solicitados, tal qual indica a Tabela 1.
A maior parte dos entrevistados considera ótima ou boa a facilidade de acesso aos serviços prestados pelos TCs subnacionais $(51,2 \%)$, bem como a qualidade da resposta (50,5\%). Em viés mais negativo, apenas $1 / 3$ dos entrevistados considera "ótimo" ou "bom" o tempo de resposta. Isso coloca a questão da celeridade e eficiência como tópico essencial para a reformulação e modernização desses tribunais.

A Tabela 2 revela, a seguir, outr a importante infor mação, referente à avaliação das atividades realizadas pelos Tribunais de Contas subnacionais.

Constata-se que os julgados do Tribunal de Contas não são considerados ótimos, mas são bem avaliados pelos entrevistados de todos os setores. $\mathrm{Na}$ média, $48 \%$ dos entrevistados consideram-nos "bons", enquanto $24,8 \%$ os avaliam como "inadequados" ou "péssimos". No que tange aos relatórios ou pareceres técnicos, a percepção é ainda mais positiva, com uma média expressiva de $56,5 \%$ de respostas assinaladas como "bom", com apenas 16,5\% de "inadequado" ou "péssimo", somados. No caso do Ministério Público, chama a atenção que a instituição é a que pior avaliação faz dos julgados do TC e a que melhor avaliação faz dos relatórios e pareceres técnicos. Judiciário e sociedade civil também apresentam essa tendência, mas de maneira menos expressiva do que a revelada pelos membros do MP. No caso do Legislativo, os percentuais relativos a avaliações positivas e negativas praticamente se repetem nos dois casos.

Grande destaque deve ser dado ao assessoramento dos técnicos do Tribunal de Contas às CPIs. Embora 1/3 não tenha se manifestado sobre esse ponto, pois ele se concentra na função legislativa, a maioria $(47,4 \%)$ julgou "ótimo" ou "bom" essa atividade e $19,5 \%$ do total a avaliou como inadequada ou péssima. Esse aspecto 
soma-se a outros em que as qualidades técnicas dos TCs subnacionais foram muito bem avaliadas. A avaliação dos servidores do órgão, exposta na Tabela 3, é outro item sobre o qual se percebe que os entrevistados têm visão positiva.

Os membros do Legislativo são os que melhor avaliam a qualificação dos servidores do Tribunal de Contas: 53,4\% consideramna boa e $14,3 \%$, excelente. Os integrantes do Controle Interno do Executivo vêm em seguida: para 51,8\%, a qualificação dos servidores do TC é boa e para 7,2\%, excelente. Já os membros do Judiciário e do Ministério Público não avaliam tão bem a qualificação dos servidores do TC. Nenhum membro do Judiciário consideraa excelente e menos da metade (41,9\%) classifica-a como boa. No caso dos integrantes do Ministério Público, o resultado não é muito diferente. Apenas 7,4\% avaliam-na como excelente e $40,7 \%$ julgam-na boa. A avaliação dos gestores e técnicos do Executivo é semelhante à realizada pelos membros do Ministério Público. Cabe destacar, no entanto, que é bastante pequena a porcentagem média dos entrevistados que avaliam negativamente a qualificação dos servidores do TC. Apenas $5,3 \%$ consideram-na inadequada para as

Tabela 1: Avaliação dos serviços solicitados ao Tribunais de Contas (em \%)

\begin{tabular}{|c|c|c|c|c|c|c|}
\hline & & Legislativo & \begin{tabular}{|l|} 
Gestores e \\
e técnicos do \\
Executivo
\end{tabular} & Judiciário & $\begin{array}{l}\text { Ministério } \\
\text { Público }\end{array}$ & $\begin{array}{l}\text { Sociedade } \\
\text { civil }\end{array}$ \\
\hline \multirow[t]{5}{*}{$\begin{array}{l}\text { 1. Facilidade de } \\
\text { acesso }\end{array}$} & ótimo & 32,5 & 8,9 & 14 & 11,1 & 9,9 \\
\hline & bom & 34,4 & 46,4 & 23,3 & 42,6 & 34,5 \\
\hline & inadequado & 9,7 & 11,9 & 7 & 16,7 & 11,3 \\
\hline & péssimo & 4,5 & 4,8 & 2,3 & 9,3 & 2,1 \\
\hline & $\begin{array}{l}\text { sem opinião/ } \\
\text { não se aplica }\end{array}$ & 18,8 & 28 & 53,5 & 20,4 & 42,3 \\
\hline \multirow[t]{5}{*}{$\begin{array}{l}\text { 2. Qualidade da } \\
\text { resposta }\end{array}$} & ótimo & 19,5 & 5,4 & 9,3 & 3,7 & 5,6 \\
\hline & bom & 44,8 & 43,5 & 32,6 & 53,7 & 34,5 \\
\hline & inadequado & 11 & 14,9 & 4,7 & 11,1 & 12 \\
\hline & péssimo & 5,2 & 2,4 & 0 & 7,4 & 4,9 \\
\hline & $\begin{array}{l}\text { sem opinião/ } \\
\text { não se aplica }\end{array}$ & 19,5 & 33,9 & 53,5 & 24,1 & 43 \\
\hline \multirow[t]{5}{*}{$\begin{array}{l}\text { 3. Tempo de } \\
\text { resposta }\end{array}$} & ótimo & 12,3 & 2,4 & 7 & 1,9 & 5,6 \\
\hline & bom & 36,4 & 33,9 & 23,3 & 22,2 & 23,9 \\
\hline & inadequado & 16,9 & 18,5 & 14 & 33,3 & 16,2 \\
\hline & péssimo & 14,3 & 12,5 & 2,3 & 16,7 & 11,3 \\
\hline & $\begin{array}{l}\text { sem opinião/ } \\
\text { não se aplica }\end{array}$ & 20,1 & 32,8 & 53,5 & 26 & 43 \\
\hline
\end{tabular}

Observação: Esta questão não foi dirigida ao Controle Interno do Executivo. 
Tabela 2: Avaliação das atividades realizadas pelos TCs (em \%)

\begin{tabular}{|c|c|c|c|c|c|}
\hline & & Legislativo & Judiciário & $\begin{array}{l}\text { Ministério } \\
\text { Público }\end{array}$ & $\begin{array}{l}\text { Sociedade } \\
\text { civil }\end{array}$ \\
\hline \multirow[t]{5}{*}{ 1. Julgados do TC } & ótimo & 9,7 & 9,3 & 5,6 & 0,7 \\
\hline & bom & 50,6 & 51,2 & 44,4 & 45,8 \\
\hline & inadequado & 14,3 & 14 & 22,2 & 19 \\
\hline & péssimo & 7,1 & 7 & 11,1 & 4,2 \\
\hline & sem opinião & 18,2 & 18,6 & 16,7 & 30,3 \\
\hline \multirow[t]{5}{*}{$\begin{array}{l}\text { 2. Relatórios e/ou pareceres } \\
\text { técnicos do TC }\end{array}$} & ótimo & 13,6 & 2,3 & 18,5 & 2,8 \\
\hline & bom & 53,2 & 58,1 & 61,1 & 53,5 \\
\hline & inadequado & 17,5 & 9,3 & 9,3 & 15,5 \\
\hline & péssimo & 3,2 & 7 & 1,9 & 2,1 \\
\hline & sem opinião & 12,3 & 23,3 & 9,3 & 26,1 \\
\hline \multirow[t]{5}{*}{$\begin{array}{l}\text { 3. Assessoramento técnico } \\
\text { do TC às Comissões } \\
\text { Parlamentares de Inquérit }\end{array}$} & ótimo & 12,3 & - & - & - \\
\hline & bom & 35,1 & - & - & - \\
\hline & inadequado & 11,7 & - & - & - \\
\hline & péssimo & 7,8 & - & - & - \\
\hline & sem opinião & 33,1 & - & - & - \\
\hline \multirow[t]{5}{*}{ 4. Publicações e estudos } & ótimo & - & 4,7 & 7,4 & 5,6 \\
\hline & bom & - & 41,9 & 31,5 & 34,5 \\
\hline & inadequado & - & 7 & 9,3 & 11,3 \\
\hline & péssimo & - & 7 & 1,9 & 3,5 \\
\hline & sem opinião & - & 39,5 & 50 & 45,1 \\
\hline \multirow[t]{5}{*}{$\begin{array}{l}\text { 5. Treinamentos e cursos } \\
\text { (atividades de capacitação) }\end{array}$} & ótimo & - & 0 & 11,1 & - \\
\hline & bom & - & 39,5 & 24,1 & - \\
\hline & inadequado & - & 2,3 & 5,6 & - \\
\hline & péssimo & - & 7 & 0 & - \\
\hline & sem opinião & - & 51,2 & 59,3 & - \\
\hline
\end{tabular}

Observações: Esta questão não foi dirigida aos gestores e técnicos nem ao Controle Inter no do Executivo. $\mathrm{O}$ item 3 não foi submetido ao Judiciário, ao Ministério Público e à sociedade civil. $\mathrm{O}$ item 4 não foi submetido ao Legislativo e o item 5 não foi submetido ao Legislativo e à sociedade civil.

suas funções e menos de $1 \%$, na média dos setores, apontou essa qualificação como péssima. Se cotejarmos essa análise com outras sobre o perfil técnico dos outros poderes, o percentual atingido pelos TCs subnacionais ainda é bastante alto.
Pelo exposto nesta seção, afere-se que os Tribunais de Contas recebem, no geral, boa avaliação de suas capacidades administrativas. É bem verdade que há alguns flancos que precisam ser mais bem tratados, porém as elites institucionais e 
Tabela 3: Avaliação sobre a qualificação dos servidores do TC (em \%)

\begin{tabular}{l|c|c|c|c|c}
\hline & Legislativo & $\begin{array}{c}\text { Gestores e } \\
\text { técnicos do } \\
\text { Executivo }\end{array}$ & $\begin{array}{c}\text { Controle } \\
\text { Interno do } \\
\text { Executivo }\end{array}$ & Judiciário & $\begin{array}{l}\text { Ministério } \\
\text { Público }\end{array}$ \\
\hline Excelente & 14,3 & 4,8 & 7,2 & 0 & 7,4 \\
\hline Boa & 53,9 & 43,5 & 51,8 & 41,9 & 40,7 \\
\hline Razoável & 23,4 & 25 & 33,7 & 20,9 & 20,4 \\
\hline Inadequada para suas funções & 3,2 & 6,5 & 1,2 & 4,7 & 5,6 \\
\hline Péssima & 1,3 & 2,4 & & 0 & 0 \\
\hline Não sei & 3,8 & 17,9 & 6 & 32,6 & 25,9 \\
\hline
\end{tabular}

Observação: Esta questão não foi dirigida à sociedade civil.

sociais emitiram opiniões que podem ser interpretadas como aprovação das capacidades administrativas dos TCs. Por essa variável, conforme os entrevistados, esses tribunais teriam as condições básicas para exercer bem suas funções de controle.

Aqui, porém, está o calcanhar de Aquiles dos Tribunais de Contas. Se a capacidade institucional básica existe, as críticas dirigem-se fortemente ao mérito de suas decisões. Essa questão pode ser af erida pela contraposição entre a independência da instituição e a politização de sua estrutura decisória. Procuramos traduzir esse dilema no questionário em termos de decisões "políticas" versus decisões "técnicas" e solicitamos aos entrevistados que identificassem a direção predominante das ações dos TCs subnacionais, tal qual revela a Tabela 4.

A boa leitura dos números revela um quadro que pode ser assim sintetizado: enquanto $2 / 3$ dos entrevistados disseram que há predominância de critérios políticos ou de injunções políticas nas decisões dos TCs subnacionais, apenas $1 / 3$ apontou $O$ predomínio da variável técnica. Observando-se as afirmações mais contundentes, nota-se que 21,9\% (na média dos setores) afirmaram que as decisões são norteadas por critérios políticos e a metade disso
$(10,3 \%)$ acreditou que as decisões são norteadas por critérios técnicos. É interessante notar a variação significativa entre os setores que compõem o conjunto estudado: no Judiciário, a diferença entre os que afirmaram o predomínio da política sobre a técnica é de 6,9 pontos percentuais (48,8\% e 41,9\%, respectivamente); no Legislativo, é de 12,3 pontos percentuais $(53,9 \%$ e $41,6 \%$, respectivamente); na sociedade civil, essa diferença avança para 39,4 pontos percentuais (67,6\% e $28,2 \%$, respectivamente); e no Ministério Público, o avaliador mais duro, a distância de posições atinge nada menos que 57,3 pontos percentuais $(77,7 \%$ e $20,4 \%$, respectivamente).

Essa avaliação feita pelas elites institucionais e sociais é preocupante. Ela coloca o tema da legitimidade externa dos TCs subnacionais como ponto chave para sua reformulação. Uma resposta mais peremptória, todavia, precisa ser formulada a partir da análise da accountability dos TCs, como se verá a seguir.

\section{A accountability dos Tribunais de Contas subnacionais}

Uma dimensão essencial a qualquer instituição pública democrática é sua 
Tabela 4: As decisões do Tribunal de Contas são norteadas por (em \%)

\begin{tabular}{l|c|c|c|c}
\hline & Legislativo & Judiciário & $\begin{array}{l}\text { Ministério } \\
\text { Público }\end{array}$ & $\begin{array}{l}\text { Sociedade } \\
\text { civil }\end{array}$ \\
\hline Critérios políticos & 16,2 & 18,6 & 29,6 & 23,2 \\
\hline Critérios técnicos & 18,2 & 7,0 & 5,6 & 10,6 \\
\hline $\begin{array}{l}\text { Uma mescla de critérios políticos e } \\
\text { técnicos, mas com predomínio das } \\
\text { injunções políticas }\end{array}$ & 37,7 & 30,2 & 48,1 & 44,4 \\
\hline $\begin{array}{l}\text { Uma mescla de critérios políticos e } \\
\text { técnicos, mas com predomínio da } \\
\text { variável técnica }\end{array}$ & 23,4 & 34,9 & 14,8 & 17,6 \\
\hline Não sei & 4,5 & 9,3 & 1,9 & 4,2 \\
\hline
\end{tabular}

Observação: Esta questão não foi dirigida aos gestores e técnicos nem ao Controle Interno do Executivo.

capacidade de responder aos cidadãos e aos seus órgãos representativos. Trata-se da temática da accountability, que pode ser definida como o controle ininterrupto dos governantes, por instrumentos verticais eleições, fundamentalmente - e horizontais - os checks and balances entre os Poderes e as instituições fiscalizadoras (ABRUCIO; Loureiro, 2005). Analisar os Tribunais de Contas pela ótica da accountability passa, primeiramente, pela avaliação do impacto de suas ações no público em geral. Nesse sentido, todos os atores entrevistados foram instados a responder como os TCs subnacionais relacionam-se com os cidadãos comuns nos aspectos tratados na Tabela 5.

Em todos os aspectos que envolvem o relacionamento do TC com o cidadão comum, listados na Tabela 5 , a avaliação negativa (soma de "inadequado" com "péssimo") predomina sobre a avaliação positiva (soma de "ótimo" e "bom"). O item que recebe a pior avaliação é justamente o da comunicação de suas atribuições institucionais para os cidadãos, com 61,3\% de inadequado/ péssimo e 18,5\% de ótimo/bom, na média dos setores. Não por coincidência, a sociedade civil é o setor que mais se queixa de deficiência nessa área, com 67,6\% das respostas considerando inadequado ou péssimo. Em seguida, vem a avaliação negativa sobre a clareza da linguagem utilizada pelos TCs para o cidadão comum, com 52,5\% de inadequado/péssimo e 24,6\% de ótimo/ bom, somados. Da mesma forma, a sociedade civil destaca-se com $60 \%$ de avaliação negativa sobre esse ponto.

As avaliações negativas sobre a transparência dada à fiscalização dos recursos públicos realizada pelo Tribunal de Contas e a facilidade de acesso aos trabalhos elaborados dessa instituição estão no mesmo patamar (algo em torno de 2 para 1), mas, nesses casos, a sociedade civil divide com o Ministério Público a responsabilidade pelos percentuais mais elevados de crítica aos TCs subnacionais. Os resultados obtidos pela fiscalização do uso dos recursos públicos receberam a avaliação menos negativa de todas (44,3\% de inadequado/ péssimo e 33,4\% de ótimo/bom), talvez por ser a mais publicizada de todas as atividades do TC.

Cabe destacar que, apesar da avaliação majoritariamente negativa da sociedade civil acerca dos aspectos da comunicação, da clarez̧a da linguagem, da transparência da fiscalização, da facilidade de acesso e dos resultados obtidos pela 
fiscalização, em questão específica aplicada nesse setor, uma ampla maioria de seus representantes $(62 \%)$ avaliou como positivo o impacto das decisões dos TCs junto à sociedade (metade afirmou que o impacto era forte e positivo e a outra metade que era fraco e positivo, segundo a Tabela 6). O distanciamento institucional e a fragilidade comunicativa provavelmente sejam fatores mais determinantes para a imagem dos Tribunais de Contas do que a falta de qualidade e capacitação técnica.
Os entrevistados responderam a um outro importante questionamento para avaliar a efetividade da accountability dos TCs subnacionais. Trata-se da relevância de algumas ações de controle externo para o aprimoramento da democracia no país. A grande maioria dos entrevistados avaliou como "muito importante" ou "importante" todas as ações fiscalizadoras realizadas pelos TCs como mecanismos de consolidação democrática. O item que recebeu maior destaque foi anditorias, com

Tabela 5: Avaliação do relacionamento do TC com o cidadão comum, nos seguintes aspectos (em\%)

\begin{tabular}{|c|c|c|c|c|c|}
\hline & & Legislativo & Judiciário & $\begin{array}{l}\text { Ministério } \\
\text { Público }\end{array}$ & $\begin{array}{l}\text { Sociedade } \\
\text { civil }\end{array}$ \\
\hline \multirow{5}{*}{$\begin{array}{l}\text { 1. Transparência dada à } \\
\text { fiscalização dos recursos } \\
\text { públicos realizada pelo TC }\end{array}$} & ótimo & 9,1 & 4,7 & 3,7 & 1,4 \\
\hline & bom & 30,5 & 23,3 & 13 & 25,4 \\
\hline & inadequado & 26,6 & 30,2 & 33,3 & 35,2 \\
\hline & péssimo & 16,2 & 18,6 & 20,4 & 20,4 \\
\hline & não sei & 17,5 & 23,3 & 29,6 & 17,6 \\
\hline \multirow{5}{*}{$\begin{array}{l}\text { 2. Resultados obtidos pela } \\
\text { fiscalização do uso dos } \\
\text { recursos públicos }\end{array}$} & ótimo & 10,4 & 2,3 & 5,6 & 1,4 \\
\hline & bom & 31,8 & 37,2 & 22,2 & 26,8 \\
\hline & inadequado & 24 & 20,9 & 29,6 & 31,7 \\
\hline & péssimo & 14,3 & 20,9 & 14,8 & 21,1 \\
\hline & não sei & 19,5 & 18,6 & 27,8 & 19 \\
\hline \multirow{5}{*}{$\begin{array}{l}\text { 3. Facilidade de acesso aos } \\
\text { trabalhos elaborados pelo TC }\end{array}$} & ótimo & 9,1 & 2,3 & 3,7 & 2,1 \\
\hline & bom & 33,1 & 23,3 & 7,4 & 23,9 \\
\hline & inadequado & 24 & 20,9 & 42,6 & 32,4 \\
\hline & péssimo & 20,1 & 20,9 & 20,4 & 19 \\
\hline & não sei & 13,6 & 32,6 & 25,9 & 22,5 \\
\hline \multirow{5}{*}{$\begin{array}{l}\text { 4. Comunicação de suas } \\
\text { atribuições institucionais } \\
\text { para os cidadãos }\end{array}$} & ótimo & 7,1 & 2,3 & 1,9 & 0,7 \\
\hline & bom & 20,1 & 14 & 11,1 & 16,9 \\
\hline & inadequado & 31,2 & 27,9 & 35,2 & 31,7 \\
\hline & péssimo & 27,9 & 27,9 & 27,8 & 35,9 \\
\hline & não sei & 13,6 & 27,9 & 24,1 & 14,8 \\
\hline \multirow{5}{*}{$\begin{array}{l}\text { 5. Clareza da linguagem } \\
\text { utilizada pelo TC para o } \\
\text { cidadão comum }\end{array}$} & ótimo & 5,8 & 0 & 3,7 & 1,4 \\
\hline & bom & 24,7 & 25,6 & 14,8 & 22,5 \\
\hline & inadequado & 33,8 & 20,9 & 35,2 & 28,2 \\
\hline & péssimo & 19,5 & 18,6 & 22,2 & 31,7 \\
\hline & não sei & 16,2 & 34,9 & 24,1 & 16,2 \\
\hline
\end{tabular}

Observação: Esta questão não foi dirigida aos gestores e técnicos do Executivo nem ao Controle Interno. 
Tabela 6: Impacto das decisões dos TCs na sociedade

\begin{tabular}{l|c}
\hline Impacto & $\%$ \\
\hline forte e positivo & 31 \\
\hline forte e negativo & 5,6 \\
\hline fraco e positivo & 31 \\
\hline fraco e negativo & 14,8 \\
\hline não têm impacto & 15,5 \\
\hline não respondeu & 2,1 \\
\hline
\end{tabular}

Observação: Esta questão foi aplicada apenas entre os representantes da sociedade civil.

$87,5 \%$ de respostas "muito importante" ou "importante", na média dos setores. O que recebeu menor destaque, ainda assim com percentual elevado, foi análise concomitante de edital de licitação, com 77,8\% de respostas "muito importante" ou "importante". Apesar de os tópicos contarem com maiorias folgadas a favor, uma análise detalhada por setor revela que o Le gislativo, o Controle Interno do Executivo e a sociedade civil entram no cômputo da média com os valores mais altos (entre $85 \%$ e $90 \%$ ), ao passo que o Judiciário e o Ministério Público dão um pouco menos de importância às ações dos TCs para o aperfeiçoamento da democracia, contribuindo com algo em torno de $70 \%$ a $75 \%$ para a composição das médias gerais de aprovação, valores que, no entanto, ainda são bastante altos.

$\mathrm{Um}$ aspecto essencial à boa accountability diz respeito à clareza das funções de determinada instituição e ao exercício correto das tarefas esperadas pela sociedade e pelos poderes públicos. A crítica a funções desnecessárias e a demanda por novas parecem vir mais fortemente dos gestores e técnicos do Executivo, seguidos de perto pelo Ministério Público. Parte significativa dos representantes da sociedade civil também requer novas atribuições para os TCs subnacionais, embora não tenham sido questionados sobre funções eventualmente supérfluas. $\mathrm{O}$ Judiciário é aquele que apresenta a menor demanda de novas tarefas para os TCs e que menos constata neles a existência de funções desnecessárias.

No caso de respostas afirmativas a essas questões, abrimos no questionário espaço para que os entrevistados dessem exemplos concretos. Entre os gestores e técnicos do Executivo, foi possível identificar quatro grandes temas, ou linhas de atuação, que esse setor gostaria de ver sendo introduzidos ou ampliados, no rol de atribuições do TC:

$\checkmark$ Tema I: Orientação, educação e prevenção;

( Tema II: Atuação pari passu, concomitante, in loco (agilidade);

○ Tema III: Avaliação dos resultados e da efetividade das políticas governamentais;

$\checkmark$ Tema IV: Mais transparência e maior contato com a sociedade civil.

Segundo os gestores e técnicos do Executivo, os TCs deveriam desenvolver mais ações no sentido de prevenção e de orientação aos administradores públicos, como forma de reduzir as irregularidades no planejamento e na execução dos gastos públicos. A função de assessoria é destacada como uma das possíveis inovações que contribuiriam para esse papel preventivo e orientador, apoiada na competência técnica dos quadros dos TCs, amplamente reconhecida não só pelos gestores e técnicos do Executivo, como pelos demais setores da amostra.

Os integrantes da burocracia do Executivo manifestaram, ainda, preocupação com a eficácia da fiscalização dos gastos públicos, mais precisamente com o timing de sua realização pelo TC. Segundo vários gestores e técnicos do Executivo, em vez de se limitarem a realizar essa fiscalização a posteriori, os TCs deveriam buscar formas 
de implementá-la pari passu, simultaneamente, à execução dos gastos públicos.

Dessas críticas, um conjunto significativo de respostas de gestores e técnicos do Executivo levantou a idéia de que o TC deve-se converter exclusivamente em órgão de fiscalização dos resultados das políticas governamentais. $\mathrm{O}$ argumento geral é de que o acompanhamento contábil, realizado $a$ posteriori, e, muitas vezes, meramente formal dos gastos públicos não contribui para o aperfeiçoamento da administração pública e, nesse sentido, o TC deveria ir além desse ponto e colocar-se como agente fiscalizador da efetividade das ações de governo. A introdução dessa função de avaliação e controle dos resultados de políticas públicas e até mesmo de acompanhamento dos processos judiciais desencadeados a partir de informações produzidas pelo próprio Tribunal levaria a instituição a assumir novo e muito mais significativo papel perante o governo e a sociedade.

Se juntarmos a preocupação com a ação mais preventiva e de auditoria simultânea à realização dos gastos e atos administrativos do Executivo, por um lado, e o pleito para que se priorize a avaliação $a$ posteriori da efetividade das políticas, por outro, poderíamos ter aí uma contradição, mas, numa outra e plausível interpretação, o que os gestores públicos estão pedindo ao Tribunal de Contas é que ele seja menos formalista e atue no conteúdo, de forma ágil e em parceria com a administração pública. Do ponto de vista da accountability, trata-se de focar mais na responsabilização por controle de resultados, um dos aspectos mais inovadores do Estado contemporâneo, que consegue combinar as preocupações democráticas com as relacionadas à melhoria de seu desempenho (CLAD, 2000).

Um quarto tema ocupou a atenção dos gestores e técnicos do Executivo: a necessidade de maior transparência e contato dos TCs com a sociedade civil. Segundo os entrevistados, os tribunais deveriam construir e aprimorar formas de divulgação e publicidade de seus atos, gerando, inclusive, ganhos de legitimidade para si mesmos.

Esse tema também foi destacado pelos representantes da sociedade civil ouvidos pela pesquisa. $\mathrm{Na}$ opinião de um deles, os TCs subnacionais deveriam aproximar-se mais da sociedade, pois hoje um TC "parece um bloco monolítico, frio, distante e insensível". Sugestões concretas foram dadas nesse sentido, abrangendo desde a realização de eventos e debates em espaços públicos, com ampla participação de setores organizados da sociedade civil, até a criação de programa de rádio ou TV para informar os cidadãos sobre os atos da instituição.

O segundo tema destacado pelos representantes da sociedade civil, também bastante instigante, tem a ver com a efetividade das ações do próprio TC. De acordo com os entrevistados, a instituição deveria buscar novas formas de garantir que suas decisões tivessem maior eficácia. Agir de ofício diante de denúncias de corrupção e executar seus próprios julgados foram algumas das sugestões feitas. Cabe registrar também que, ao se preocuparem com a questão da efetividade das ações dos TCs, representantes da sociedade civil levantam dúvida sobre a capacidade de esses tribunais fiscalizarem e julgarem, tecnicamente, com isenção e independência, os políticos.

Da mesma forma que os gestores e técnicos do Executivo, também os representantes da sociedade civil enxergam, nas funções de orientação, educação e prevenção, um caminho importante que poderia ser trilhado pelo TC.

A questão sobre atividades que o Tribunal de Contas realiza e não deveria realizar abriu 
espaço para que os entrevistados registrassem suas suspeitas e críticas e as concentrassem em um ponto fulcral, já notado anteriormente: a politização indevida dos TCs subnacionais e a falta de isenção, de neutralidade e de imparcialidade de suas ações. Ou seja, mais do que citar funções supérfluas ou desnecessárias, uma grande parcela dos atores fez aqui forte crítica ao desvio político que afirmam ocorrer nesses tribunais. O Quadro 2 retrata essa situação, segundo a visão predominante em alguns dos grupos pesquisados.

Para que os Tribunais de Contas subnacionais possam exercer adequadamente a accountability, além de saber quais são as funções que deveriam exercer e hoje não fazem, bem como quais são as atividades ou ações realizadas tachadas de indevidas, buscou-se saber o que os entrevistados acreditavam ser os maiores problemas e as maiores qualidades dos TCs. Por meio de questões abertas, nada menos do que $90 \%$ dos entrevistados (na média dos seis setores) elaboraram frases e pequenos parágrafos sobre o primeiro aspecto e $83 \%$ deles fizeram o mesmo sobre o segundo.

Três problemas dos TCs foram mais realçados pelos entrevistados, a saber:

$\square$ politização do Tribunal e falta de independência;

$\square$ falta de transparência e de relação com a sociedade;

$\square$ burocratização das atividades e lentidão das respostas.

Desses, a politização e a falta de independência do Tribunal - é, sem dúvida, o que mais se destacou. A maior parte das respostas apontou esse problema como o mais grave na caracterização dos TCs subnacionais. A politização indesejável da instituição acometeria suas diversas dimensões, conformando-lhe imagem externa bastante negativa: o processo de escolha dos conselheiros, decisões políticas contrariando aspectos técnicos, ingerência externa no funcionamento do TC, ações políticas de perseguição a adversários e omissões graves diante de correligionários, da corrupção e do nepotismo. Não foram

Quadro 2: Frases de parlamentares, gestores e técnicos do Executivo e de membros do Ministério Público sobre a questão "atividades que o TC realiza e não deveria realizar”

\begin{tabular}{|l|l|}
\hline & Politização indevida do Tribunal de Contas \\
\hline Legislativo & Apreciar contas do poder público sobre o prisma político. \\
\hline & Envolve-se muito em política. \\
\hline & Interferir politicamente nos bastidores das decisões políticas. \\
\hline Gestores e técnicos & Age politicamente na apreciação de contas. \\
\hline do Executivo & Ignorar a legalidade, imparcialidade. \\
\hline & Deixar de agir politiqueiramente. \\
\hline Ministério Público & Julgamento político de contas governamentais. \\
\hline & Ingerência nos órgãos para atender um reclamo político. \\
\hline & Perseguir os inimigos políticos e deixar seus amigos sem punição. \\
\hline
\end{tabular}


poucos os que utilizaram a expressão “politicagem" para definir, em uma só palavra, o que seria o maior problema dos TCs. Houve quem afirmasse que a instituição não é um "tribunal de verdade", pois sua composição seria "altamente política". Outro entrevistado resumiu o dilema da politização do tribunal versus cumprimento efetivo de suas obrigações institucionais da seguinte forma: "Falta de independência. Precisa explicar?”.

No que diz respeito à maior qualidade do TC, um número significativo de entrevistados respondeu simplesmente que não havia nenhuma ou que desconhecia qualidades dignas de nota. Em uma das respostas mais contundentes da pesquisa, um parlamentar afir mou: "Não vejo nenhuma, apenas o abrigo de casos de nepotismo, de má gestão e de apadrinhamento político, sem ajudar a cortar gastos, sem serventia para a sociedade, gerando apenas despesa para o Estado’.

Entretanto, cabe registrar que encontramos também várias frases elogiosas em relação à transparência de alguns TCs subnacionais e outras destacando a agilidade com que determinadas Cortes respondem a consultas e processos. Em termos mais específicos, houve comentários destacando a "contínua busca de processos de modernização e aperfeiçoamento" de muitos TCs - frase que apareceu com grande freqüência. Um parlamentar chegou a afirmar: "Acho que é honesta a intenção de se autoreformarem, ainda que as mudanças ocorram lentamente". Representantes da sociedade civil ressaltaram "o interesse de mudar seu estado de inércia atual, aproximando-se da sociedade" e "a busca de melhoria operacional, agilidade e transparência" como características de alguns TCs. Entre os membros do Ministério Público igualmente encontramos quem destacasse "a busca, ainda que tímida e limitada, da melhoria da qualidade de seus serviços de fiscalização das gestões públicas" e "o desenvolvimento de um projeto de modernização".

Entre as qualidades mencionadas, duas ocorreram em número bastante significativo e merecem ser agrupadas por temas, a saber:

$\square$ a competência técnica e a qualidade do corpo de funcionários;

$\square$ a importância do papel institucional conferido aos TCs.

Não seria exagero afirmar que é na qualidade do corpo de funcionários dos tribunais e na competência técnica da instituição que reside o maior "capital de legitimidade" que os TCs detêm hoje.

Associados à dimensão técnica, alguns comentários destacaram igualmente, como pontos positivos, o grau de infor matização dos TCs, a estrutura física e material de muitos deles, a remuneração de seus servidores e as condições de trabalho da instituição. De maneira evidente, por exemplo, promotores e procuradores do Ministério Público demonstraram especial interesse em estabelecer parcerias com os TCs subnacionais justamente por essas qualidades, não encontradas na maior parte dos MPs estaduais, que se ressentem da falta de corpo técnico especializado e de instalações físicas adequadas.

Outro conjunto significativo de respostas à pergunta sobre a maior qualidade do Tribunal de Contas destacou a importância do seu papel institucional no sistema político brasileiro, revelando que, para boa parte dos entrevistados, as críticas eventuais ao funcionamento dos TCs não devem colocar em dúvida sua imprescindibilidade para a democracia. Afinal, como afirmaram alguns entrevistados, a maior qualidade da instituição é, no mínimo, "o fato de impor uma certa dor de cabeça aos gestores mal-intencionados" e "a sua existência mesma, bem ou mal, coíbe práticas abusivas do Executivo". 
Sob o prisma da accountability, é possível dizer que os TCs subnacionais, na opinião das elites sociais e institucionais entrevistadas, ainda necessitam tornar mais transparentes suas ações, mais claras suas funções, melhorar seu desempenho em prol da agilidade e do tratamento mais adequado a seus usuários e, sobretudo, despolitizar suas decisões. Cumprir essa agenda reformista levará ao reforço da legitimidade dos TCs.

\section{Propostas para reformulação dos Tribunais de Contas}

Os entrevistados também foram instados a propor e/ou analisar aspectos que poderiam melhorar a qualidade e o desempenho dos TCs subnacionais. Num primeiro momento, defrontaram-se com uma lista de sugestões de mudança e atribuíram peso a cada aspecto, conforme a Tabela 7 demonstra.

$\mathrm{Na}$ média dos setores selecionados, algo entre $80 \%$ e $87 \%$ dos entrevistados considera as 14 sugestões de melhoria dos resultados da atuação do TC como "muito importantes" ou "importantes".

No que diz respeito ao item "abreviar o tempo de resposta”, a maior taxa de aprovação da idéia ficou com os membros do Legislativo (91,5\%), que dependem diretamente dos trabalhos dos TCs para exercer o papel de fiscais do Executivo, e a menor foi dada pelos membros do Judiciário $(74,5 \%)$.

A sugestão de manter um canal mais direto com o Poder Executivo recebe as maiores taxas de aprovação (importante ou muito importante) entre os próprios gestores e técnicos do Executivo e os membros do Controle Interno, com 91\% e $91,5 \%$, respectivamente. Isso reforça o que foi mostrado no início do artigo: o Poder Executivo considera fundamental a melhoria de suas relações com o TC.
Os atores que se relacionam diretamente com esses tribunais também consideram importante ou muito importante a existência de um canal mais direto com o ór gão. Tal intenção aparece no Legislativo, com 93,5\%; no Judiciário, com 79,1\%; e no Ministério Público, com 92,6\%. Finalizando, 92,3\% dos representantes da sociedade civil entrevistados também consideram importante a existência de um canal de comunicação direto com o TC. Verifica-se, portanto, que tanto os atores públicos quanto os sociais gostariam de estabelecer maior aproximação com o Tribunal de Contas, por meio de canais diretos efetivos.

A padronização de decisões (julgar de maneira uniforme independente de quem seja o gestor) surge como preocupação comum a todos os atores entrevistados. A maior ênfase é dada pelos membros do Ministério Público (com 88,9\% de “importante" e "muito importante") e a menor taxa verifica-se nos entrevistados do Poder Legislativo $(84,4 \%)$.

Também importante - e já colocada em outro momento desta pesquisa como um dos desafios para os Tribunais de Contas - é a avaliação de resultados dos programas de governo. Tal questão é vista como importante ou muito importante por 97,6\% dos entrevistados do Controle Interno do Executivo e a menor ênfase é atribuída pelos membros do Judiciário $(81,4 \%)$, mesmo assim num patamar alto de indicação. Um total de 89,3\% dos gestores e técnicos do Poder Executivo igualmente desejam que os TCs assumam tal atribuição. Isso demonstra que, para além dos requisitos da legalidade, legitimidade e economicidade, os membros do Poder Executivo participantes da pesquisa querem que os TCs concentrem-se, cada vez mais, na avaliação do alcance de suas politicas governamentais no momento do julgamento de suas contas. 
Tabela 7: Importância de propostas para melhorar os resultados da atuação do Tribunal de Contas (em \%)

\begin{tabular}{|c|c|c|c|c|c|}
\hline 1. Abreviar o tempo de resposta & $\begin{array}{l}\text { muito } \\
\text { importante }\end{array}$ & importante & $\begin{array}{l}\text { pouco } \\
\text { importante }\end{array}$ & $\begin{array}{l}\text { sem } \\
\text { importância }\end{array}$ & sem opinião \\
\hline Legislativo & 61 & 30,5 & 3,9 & 0,6 & 3,9 \\
\hline Gestores e técnicos do Executiv & 45,8 & 41,1 & 3,6 & 1,2 & 8,3 \\
\hline Controle Interno do Executivo & 62,7 & 27,7 & 4,8 & 1,2 & 3,6 \\
\hline Judiciário & 51,2 & 23,3 & 4,7 & 2,3 & 18,6 \\
\hline Ministério Público & 53,7 & 33,3 & 3,7 & 1,9 & 7,4 \\
\hline Sociedade civil & 57,7 & 32,4 & 0,7 & 0,7 & 8,5 \\
\hline $\begin{array}{l}\text { 2. Manter um canal direto mais } \\
\text { efetivo com o Poder Legislativo }\end{array}$ & $\begin{array}{l}\text { muito } \\
\text { importante }\end{array}$ & importante & \begin{tabular}{|l} 
pouco \\
importância
\end{tabular} & $\begin{array}{l}\text { sem } \\
\text { importância }\end{array}$ & sem opinião \\
\hline Legislativo & 68,2 & 25,3 & 3,2 & 0 & 3,2 \\
\hline Gestores e técnicos do Executiv & 34,5 & 43,5 & 7,1 & 2,4 & 12,5 \\
\hline Controle Interno do Executivo & 32,5 & 49,4 & 9,6 & 1,2 & 7,2 \\
\hline Judiciário & 34,9 & 44,2 & 2,3 & 4,7 & 14 \\
\hline Ministério Público & 35,2 & 27,8 & 20,4 & 1,9 & 14,8 \\
\hline Sociedade civil & 43,7 & 42,3 & 7 & 1,4 & 5,6 \\
\hline $\begin{array}{l}\text { 3. Manter um canal direto mais } \\
\text { efetivo com o Poder Executivo }\end{array}$ & $\begin{array}{l}\text { muito } \\
\text { importante }\end{array}$ & importante & $\begin{array}{l}\text { pouco } \\
\text { importância }\end{array}$ & $\begin{array}{l}\text { sem } \\
\text { importância }\end{array}$ & sem opinião \\
\hline Legislativo & 46,8 & 31,2 & 13 & 3,9 & 5,2 \\
\hline Gestores e técnicos do Executiv & 56,5 & 34,5 & 3 & 1,2 & 4,8 \\
\hline Controle Interno do Executivo & 60,2 & 31,3 & 6 & 0 & 2,4 \\
\hline Judiciário & 34,9 & 44,2 & 2,3 & 4,7 & 14 \\
\hline Ministério Público & 24,1 & 37 & 22,2 & 1,9 & 14,8 \\
\hline Sociedade civil & 44,4 & 38,7 & 10,6 & 1,4 & 4,9 \\
\hline $\begin{array}{l}\text { 4. Identificar as necessidades dos } \\
\text { agentes que utilizam os serviços do TC }\end{array}$ & $\begin{array}{l}\text { muito } \\
\text { importante }\end{array}$ & importante & $\begin{array}{l}\text { pouco } \\
\text { importância }\end{array}$ & $\begin{array}{l}\text { sem } \\
\text { opinião }\end{array}$ & $\begin{array}{l}\text { sem } \\
\text { importante }\end{array}$ \\
\hline Legislativo & 36,4 & 52,6 & 2,6 & 1,3 & 7,1 \\
\hline $\begin{array}{l}\text { Gestores e técnicos do } \\
\text { Executivo }\end{array}$ & 51,8 & 30,4 & 8,9 & 0,6 & 8,3 \\
\hline Controle Interno do Executivo & 55,4 & 36,1 & 7,2 & 0 & 1,2 \\
\hline Judiciário & 34,9 & 30,2 & 4,7 & 2,3 & 27,9 \\
\hline Ministério Público & 55,6 & 31,5 & 5,6 & 0 & 7,4 \\
\hline Sociedade civil & 55,6 & 32,4 & 7 & 0,7 & 4,2 \\
\hline
\end{tabular}


(... continuação da Tabela 7)

\begin{tabular}{|c|c|c|c|c|c|}
\hline $\begin{array}{l}\text { 5. Reduzir a formalidade no } \\
\text { trâmite dos processos }\end{array}$ & $\begin{array}{l}\text { muito } \\
\text { importante }\end{array}$ & importante & $\begin{array}{l}\text { pouco } \\
\text { importante }\end{array}$ & $\begin{array}{l}\text { sem } \\
\text { importância }\end{array}$ & $\begin{array}{l}\text { sem } \\
\text { opinião }\end{array}$ \\
\hline Legislativo & 44,8 & 36,4 & 13 & 1,9 & 3,9 \\
\hline $\begin{array}{l}\text { Gestores e técnicos do } \\
\text { Executivo }\end{array}$ & 60,7 & 27,4 & 4,8 & 0 & 7,1 \\
\hline Controle Interno do Executivo & 57,8 & 28,9 & 9,6 & 1,2 & 2,4 \\
\hline Judiciário & 48,8 & 27,9 & 0 & 2,3 & 20,9 \\
\hline Ministério Público & 53,7 & 38,9 & 3,7 & 0 & 3,7 \\
\hline Sociedade civil & 50 & 33,8 & 9,2 & 1,4 & 5,6 \\
\hline $\begin{array}{l}\text { 6. Decidir de modo uniforme } \\
\text { os casos ou matérias similares }\end{array}$ & $\begin{array}{l}\text { muito } \\
\text { importante }\end{array}$ & importante & $\begin{array}{l}\text { pouco } \\
\text { importante }\end{array}$ & $\begin{array}{l}\text { sem } \\
\text { importância }\end{array}$ & $\begin{array}{l}\text { sem } \\
\text { opinião }\end{array}$ \\
\hline Legislativo & 43,5 & 40,9 & 6,5 & 1,9 & 7,1 \\
\hline $\begin{array}{l}\text { Gestores e técnicos do } \\
\text { Executivo }\end{array}$ & 50,6 & 32,7 & 10,1 & 0 & 6,5 \\
\hline Controle Interno do Executivo & 62,7 & 33,7 & 1,2 & 0 & 2,4 \\
\hline Judiciário & 58,1 & 23,3 & 0 & 2,3 & 16,3 \\
\hline Ministério Público & 68,5 & 20,4 & 3,7 & 0 & 7,4 \\
\hline Sociedade civil & 44,4 & 42,3 & 6,3 & 1,4 & 5,6 \\
\hline $\begin{array}{l}\text { 7. Divulgar os relatórios } \\
\text { técnicos juntamente com as } \\
\text { decisões do Colegiado }\end{array}$ & $\begin{array}{l}\text { muito } \\
\text { importante }\end{array}$ & importante & $\begin{array}{l}\text { pouco } \\
\text { importante }\end{array}$ & $\begin{array}{l}\text { sem } \\
\text { importância }\end{array}$ & $\begin{array}{l}\text { sem } \\
\text { opinião }\end{array}$ \\
\hline Legislativo & 52,6 & 38,3 & 6,5 & 1,3 & 1,3 \\
\hline $\begin{array}{l}\text { Gestores e técnicos do } \\
\text { Executivo }\end{array}$ & 41,1 & 41,7 & 10,1 & 0 & 7,1 \\
\hline Controle Interno do Executivo & 49,4 & 42,2 & 3,6 & 1,2 & 3,6 \\
\hline Judiciário & 39,5 & 39,5 & 2,3 & 4,7 & 14 \\
\hline Ministério Público & 63 & 27,8 & 1,9 & 1,9 & 5,6 \\
\hline Sociedade civil & 51,4 & 36,6 & 5,6 & 0 & 6,3 \\
\hline $\begin{array}{l}\text { 8. Priorizar o controle } \\
\text { de legalidade }\end{array}$ & $\begin{array}{l}\text { muito } \\
\text { importante }\end{array}$ & importante & $\begin{array}{l}\text { pouco } \\
\text { importante }\end{array}$ & $\begin{array}{l}\text { sem } \\
\text { importância }\end{array}$ & $\begin{array}{l}\text { sem } \\
\text { opinião }\end{array}$ \\
\hline Legislativo & 55,2 & 37 & 3,2 & 0,6 & 3,9 \\
\hline $\begin{array}{l}\text { Gestores e técnicos do } \\
\text { Executivo }\end{array}$ & 43,5 & 42,3 & 10,7 & 0 & 3,6 \\
\hline Controle Interno do Executivo & 26,5 & 53 & 15,7 & 2,4 & 2,4 \\
\hline Judiciário & 53,5 & 30,2 & 0 & 2,3 & 14 \\
\hline Ministério Público & 68,5 & 24,1 & 3,7 & 0 & 3,7 \\
\hline Sociedade civil & 58,5 & 31 & 3,5 & 2,1 & 4,9 \\
\hline
\end{tabular}


(... continuação da Tabela 7)

\begin{tabular}{|c|c|c|c|c|c|}
\hline $\begin{array}{l}\text { 9. Priorizar o controle } \\
\text { da economicidade }\end{array}$ & $\begin{array}{l}\text { muito } \\
\text { importante }\end{array}$ & importante & $\begin{array}{l}\text { pouco } \\
\text { importante }\end{array}$ & $\begin{array}{l}\text { sem } \\
\text { importância }\end{array}$ & $\begin{array}{l}\text { sem } \\
\text { opinião }\end{array}$ \\
\hline Legislativo & 46,1 & 44,2 & 5,2 & 0 & 4,5 \\
\hline $\begin{array}{l}\text { Gestores e técnicos do } \\
\text { Executivo }\end{array}$ & 55,2 & 40,5 & 6,5 & 0,6 & 7,1 \\
\hline Controle Interno do Executivo & 43,4 & 49,4 & 4,8 & 0 & 2,4 \\
\hline Judiciário & 44,2 & 37,2 & 0 & 2,3 & 16,3 \\
\hline Ministério Público & 51,9 & 40,7 & 3,7 & 0 & 3,7 \\
\hline Sociedade civil & 45,8 & 41,5 & 7 & 0,7 & 4,9 \\
\hline $\begin{array}{l}\text { 10. Priorizar a avaliação de } \\
\text { resultados dos programas } \\
\text { governo }\end{array}$ & $\begin{array}{l}\text { muito } \\
\text { importante }\end{array}$ & importante & $\begin{array}{l}\text { pouco } \\
\text { importante }\end{array}$ & $\begin{array}{l}\text { sem } \\
\text { importância }\end{array}$ & $\begin{array}{l}\text { sem } \\
\text { opinião }\end{array}$ \\
\hline Legislativo & 50,6 & 35,7 & 7,1 & 1,9 & 4,5 \\
\hline $\begin{array}{l}\text { Gestores e técnicos do } \\
\text { Executivo }\end{array}$ & 65,5 & 23,8 & 6 & 0 & 4,8 \\
\hline Controle Interno do Executivo & 78,3 & 19,3 & 1,2 & 0 & 1,2 \\
\hline Judiciário & 41,9 & 39,5 & 2,3 & 2,3 & 14 \\
\hline Ministério Público & 50 & 33,3 & 11,1 & 0 & 5,6 \\
\hline Sociedade civil & 43,7 & 42,3 & 7,7 & 2,1 & 4,2 \\
\hline $\begin{array}{l}\text { 11. Ampliar a disseminação } \\
\text { de conhecimentos para os } \\
\text { jurisdicionados }\end{array}$ & $\begin{array}{l}\text { muito } \\
\text { importante }\end{array}$ & importante & $\begin{array}{l}\text { pouco } \\
\text { importante }\end{array}$ & $\begin{array}{l}\text { sem } \\
\text { importância }\end{array}$ & $\begin{array}{l}\text { sem } \\
\text { opinião }\end{array}$ \\
\hline Legislativo & 37,7 & 50 & 5,8 & 0,6 & 5,8 \\
\hline $\begin{array}{l}\text { Gestores e técnicos do } \\
\text { Executivo }\end{array}$ & 44,6 & 39,3 & 7,7 & 1,2 & 7,1 \\
\hline Controle Interno do Executivo & 65,1 & 30,1 & 1,2 & 0 & 3,6 \\
\hline Judiciário & 37,2 & 41,9 & 4,7 & 2,3 & 14 \\
\hline Ministério Público & 40,7 & 46,3 & 7,4 & 0 & 5,6 \\
\hline Sociedade civil & 44,4 & 45,1 & 5,6 & 0,7 & 4,2 \\
\hline $\begin{array}{l}\text { 12. Debater mais suas ações } \\
\text { com a sociedade }\end{array}$ & $\begin{array}{l}\text { muito } \\
\text { importante }\end{array}$ & importante & $\begin{array}{l}\text { pouco } \\
\text { importante }\end{array}$ & $\begin{array}{l}\text { sem } \\
\text { importância }\end{array}$ & $\begin{array}{l}\text { sem } \\
\text { opinião }\end{array}$ \\
\hline Legislativo & 59,1 & 29,9 & 7,1 & 1,3 & 2,6 \\
\hline $\begin{array}{l}\text { Gestores e técnicos do } \\
\text { Executivo }\end{array}$ & 55,4 & 31,5 & 7,7 & 0 & 5,4 \\
\hline Controle Interno do Executivo & 56,6 & 33,7 & 6 & 1,2 & 2,4 \\
\hline Judiciário & 46,5 & 32,6 & 2,3 & 4,7 & 14 \\
\hline Ministério Público & 48,1 & 38,9 & 5,6 & 1,9 & 5,6 \\
\hline Sociedade civil & 64,1 & 28,2 & 2,1 & 1,4 & 4,2 \\
\hline
\end{tabular}


(... continuação da Tabela 7)

\begin{tabular}{|c|c|c|c|c|c|}
\hline $\begin{array}{l}\text { 13. Manter canal direto mais } \\
\text { efetivo com o poder judiciário }\end{array}$ & $\begin{array}{l}\text { muito } \\
\text { importante }\end{array}$ & importante & $\begin{array}{l}\text { pouco } \\
\text { importante }\end{array}$ & $\begin{array}{l}\text { sem } \\
\text { importância }\end{array}$ & $\begin{array}{l}\text { sem } \\
\text { opinião }\end{array}$ \\
\hline Legislativo & - & - & - & - & - \\
\hline $\begin{array}{l}\text { Gestores e técnicos do } \\
\text { Executivo }\end{array}$ & - & - & - & - & - \\
\hline Controle Interno do Executivo & - & - & - & - & - \\
\hline Judiciário & 41,9 & 37,2 & 4,7 & 2,3 & 14 \\
\hline Ministério Público & 37 & 29,6 & 18,5 & 3,7 & 11,1 \\
\hline Sociedade civil & - & - & - & - & - \\
\hline $\begin{array}{l}\text { 14. Manter canal direto mais } \\
\text { efetivo com o Minitério Público }\end{array}$ & $\begin{array}{l}\text { muito } \\
\text { importante }\end{array}$ & importante & $\begin{array}{l}\text { pouco } \\
\text { importante }\end{array}$ & $\begin{array}{l}\text { sem } \\
\text { importância }\end{array}$ & $\begin{array}{l}\text { sem } \\
\text { opinião }\end{array}$ \\
\hline Legislativo & - & - & - & - & - \\
\hline $\begin{array}{l}\text { Gestores e técnicos do } \\
\text { Executivo }\end{array}$ & - & - & - & - & - \\
\hline Controle Interno do Executivo & - & - & - & - & - \\
\hline Judiciário & 51,2 & 34,9 & 0 & 2,3 & 11,6 \\
\hline Ministério Público & 77,8 & 14,8 & 3,7 & 0 & 3,7 \\
\hline Sociedade civil & - & - & - & - & - \\
\hline
\end{tabular}

Observação: os ítens 13 e 14 só foram submetidos ao Judiciário e Ministério Público

Para detectar um aspecto mais qualitativo, foi pedido aos entrevistados que destacassem quais pontos principais seriam necessários para que os TCs subnacionais efetivamente melhorassem. O Quadro 3 destaca, de forma sintética, em ordem de citação pelas elites sociais e institucionais, os aspectos essenciais para se moldar uma reforma que reconstrua a identidade dos TCs.

\section{Conclusão}

Ao final, destacamos brevemente os principais aspectos constatados pela pesquisa e relatados neste artigo.

Em primeiro lugar, os Tribunais de Contas subnacionais são relativamente conhecidos por todos os atores e poucos foram os que deslegitimaram, a princípio, sua existência. No entanto, a forma de

\section{Quadro 3: Como deveria ser o Tribunal de Contas: cinco principais aspectos}

\begin{tabular}{|l|}
\hline $1^{\circ}$ lugar - Independência institucional, composição e desempenho apolíticos \\
\hline $2^{\circ}$ lug ar - Transparência, principalmente com relação à sociedade \\
\hline $3^{\circ}$ lugar - Agilidade \\
\hline $4^{\circ}$ lug ar - Orientação, auxílio, educação e prevenção \\
\hline $\begin{array}{l}5^{\circ} \text { lugar - Perseguir seu papel institucional, melhorando a efetividade de suas ações } \\
\text { administrativas }\end{array}$ \\
\hline
\end{tabular}


exercer suas atividades é criticada pelos entrevistados em vários aspectos, tanto no que se refere à sua forma de gestão, como, e de maneira incisiva, no que tange ao mérito de suas decisões. Em poucas palavras, o survey com as elites sociais e institucionais apontou os dois principais rumos de reforma dos TCs: o aprimoramento dos instrumentos administrativos e a relegitimação institucional.

Destaca-se, ainda, que há sérios problemas de comunicação com os atores do Executivo e da sociedade civil. Todos os entrevistados, e não apenas os vinculados às organizações sociais, queixaram-se da maneira como os TCs apresentam-se e lidam com os cidadãos. Quanto mais próximos da população e transparentes forem os TCs subnacionais, mais apoio social terão para suas ações. Isso pode se chocar com a percepção de politização de sua estrutura, conforme a visão dos entrevistados, mas, talvez, essa tensão seja um primeiro passo para uma reformulação mais profunda de seu funcionamento, em prol das atribuições que a maioria dos entrevistados ainda acredita que devam ser realizadas pelos TCs.

Chama muito a atenção o relacionamento mal resolvido com as burocracias estaduais e municipais, as quais, aliás, manifestaram forte desejo de reordenamento dos TCs e de aproximação maior com eles no processo de controle, ao mesmo tempo em que um grande número dos expoentes dessas burocracias ouvidos disse não sofrer muita fiscalização dos TCs. Aparentemente, há um estranho paradoxo nessa percepção: poder-se-ia supor que os problemas de comunicação derivariam da necessária independência desses tribunais; todavia, os fiscalizados afirmaram que não são muito cobrados. O fato é que maior interligação e entrosamento com o Executivo podem ser feitos com a manutenção e o reforço de sua autoridade.
O campo da gestão foi bastante apurado pela pesquisa. Entre os maiores problemas, foram citados, com grande freqüência, a falta de agilidade, o burocratismo, o uso de linguagem muito hermética e, principalmente, a necessidade de exercer, com maior ênfase, a função de avaliação e controle de resultados. Este último aspecto é o que mais merece reflexão. Em estudo recente, Michael Barzelay (2002) mostrou como os órgãos incumbidos de controlar e auditar os governos passam por reformas profundas em várias partes do mundo. Sua função básica tem-se focado cada vez mais no acompanhamento dos gastos públicos para avaliar a qualidade e os resultados dos programas (BARZELAY, 2002).

É preciso fazer essa mesma mudança nos TCs brasileiros e, tal como a LRF, que, segundo os entrevistados, reforçou o papel desses tribunais na fiscalização das finanças públicas, seria necessário criar algum tipo de incentivo legal para que eles concentrem suas preocupações no tema do desempenho da gestão pública, em vez de atuarem basicamente pela lógica do formalismo. Nesse sentido, alterar as leis orçamentárias e mesmo obrigar os governos a definir metas e meios que possam ser acompanhados são passos fundamentais para adequar os Tribunais de Contas à nova visão de controle que se espalha pelo mundo.

Os pontos mais positivos dos TCs estão em sua qualidade técnica e estrutura administrativa. Essa vantagem deve ser utilizada como principal impulso ao processo de modernização, angariando apoio para as mudanças aqui citadas e o fortalecimento de sua legitimidade. É por sua capacitação técnica, também, que os TCs podem atrair o interesse de outras instituições por parcerias, como propuseram os membros do Ministério Público, e responder à demanda por abertura de 
mais espaços de relacionamento, como pediram principalmente os entrevistados ligados à sociedade civil e ao Executivo.

Como esperado pelas hipóteses iniciais, o grande problema dos Tribunais de Contas subnacionais é a imagem de instituição extremamente politizada. Sua reformulação passa necessariamente por esse ponto, até porque se constatou que a função fiscalizadora é muito valorizada pela sociedade e pelos poderes públicos, fato que justifica a existência dos TCs, mas, so zinho, não os sustenta. Os TCs precisam fazer das críticas efetuadas pelas elites sociais e institucionais um mapa que seja o guia de sua transformação e de seu revigoramento.

\section{Notas}

${ }^{1}$ Este artigo resume a pesquisa realizada para o Ministério do Planejamento, no bojo do Programa de Modernização do Sistema de Controle Externo dos Estados e do Distrito Federal (Promoex). O relatório geral contém um número maior de informações e pode ser encontrado no sítio www.planejamento.gov.br, no link vinculado ao Promoex.

${ }^{2}$ Além dos autor es citados, Vítor Marchetti e Karen Fernande z também participaram como pesquisadores desse projeto.

\section{Referências bibliográficas}

Abrucio, Fernando Luiz; Loureiro, Maria Rita. Finanças públicas, democracia e accountability. In: Arvate, Paulo; Biderman, Ciro (Org.). Economia do setor público no Brasil. Rio de Janeiro: Campus/Elsevier, 2005.

Arantes, Rogério Bastos. Ministério Público e política no Brasil. São Paulo: EDUC/FAPESP, 2002.

BARZELAY, Michael. Instituições centrais de auditoria e auditoria de desempenho: uma análise comparativa das estratégias organizacionais na OCDE. In: Tribunal de Contas da União. Controle Externo e a nova administração pública: uma visão comparativa. Brasília, 2002. CLAD. La responsabilización en la nueva gestión pública latinoamericana. Buenos Aires: CLAD/ BID; Eudeba, 2000.

Lamounier, Bolívar; Souza, Amaury de. As elites brasileiras e a modernização do setor público. um debate. São Paulo: Editora Sumaré/FAPESP/Fundação Ford, 1992.

Mansour, Tatiana Rebello. Tribunal de Contas do Acre - Considerações sobre eficiência e Eficácia do Controle Externo. 2001. Dissertação. (Mestrado em Administração Pública e Governo) - Escola de Administração de Empresas da Fundação Getulio Vargas. São Paulo.

Martins, Carlos Estevam. Governabilidade e controles. RAP: Revista de Administração Pública, Rio de Janeiro, v. 1, n. 23, 1989. 
Mazzon, José Afonso; Nogueira, Roberto. Projeto de prestação de serviço especializado para realização de pesquisa e proposição de iniciativas para adequada implantação da Lei de Responsabilidade Fiscal (LRF) pelos Tribunais de Contas estaduais e municipais. Relatório de pesquisa. FLA-USP. São Paulo, 2002.

Olviverra, Telma Almeida. O controle da eficiência da Administração Pública no Brasil. 1994. Dissertação. (Mestrado em Administração) - Universidade Federal da Bahia, Salvador. SPECK, Bruno. Inovação e rotina no Tribunal de Contas da União. São Paulo: Fundação Konrad Adenauer, 2000.

(Org.). Caminhos da transparência. Campinas, SP: Unicamp, 2002.

STRAuss, Daniel. A accountability no sistema antitruste brasileiro: as indefinições de seu desenvolvimento institucional. 2005. Dissertação. (Mestrado em Administração Pública e Governo) - Escola de Administração de Empresas da Fundação Getúlio Vargas, São Paulo.

TeIXeIra, Marco Antonio Carvalho. Entre o técnico e o político - O Tribunal de Contas do Município de São Paulo e o controle financeiro das gestões Luiza Erundina (19891992) e Paulo Maluf (1993-1996). 2004. Tese. (Doutorado) - Programa de Pós-Graduação em Ciências Sociais da PUC-SP, São Paulo. 


\section{Resumo - Resumen - Abstract}

\section{A imagem dos tribunais de contas subnacionais}

Rogério Bastos Arantes, Fernando Luiz Abrucio e Marco Antonio Carvalbo Teixeira

O presente artigo expõe a visão que as elites sociais e institucionais têm sobre os Tribunais de Contas (TCs) subnacionais brasileiros. Realizada no bojo do processo de diagnóstico e reforma dos TCs, o Programa de Modernização do Sistema de Controle Externo dos Estados e do Distrito Federal (Promoex), esta pesquisa revela quais são os problemas que afetam o desempenho administrativo e a legitimidade institucional desses órgãos fiscalizadores, bem como as suas qualidades, as quais podem ser utilizadas como motor de sua refor mulação. A partir da interpretação das opiniões dos atores entrevistados, a análise final procura revelar quais caminhos podem ser trilhados para se modernizarem os Tribunais de Contas subnacionais.

\section{La imagen de los Tribunales de Cuentas subnacionales brasileños}

\section{Rogério Bastos Arantes, Fernando Luiz, Abrucio y Marco Antonio Carvalho Teixeira}

Este artículo expone la visión de las elites sociales e institucionales sobre los Tribunales de Cuentas (TCs) subnacionales brasileños. Realizada en el contexto del diagnóstico y proceso de reforma de los TCS, el Programa de Modernización del Sistema de Control Externo de Estados y Municipios (Promoex), esta investigación revela los problemas que afectan el desempeño administrativo y la legitimidad institucional de esas entidades fiscalizadoras, además de sus cualidades. A partir de la interpretación de las opiniones emitidas por los actores entrevistados y encuestados, el análisis final busca mostrar cuáles son los caminos a seguir para modernizar los Tribunales de Cuentas subnacionales.

\section{The image of the Brazilian subnational Courts of Audit}

Rogério Bastos Arantes, Fernando Luiz, Abrucio and Marco Antonio Carvalho Teixeira

This article presents findings of a survey among social and institutional elites showing how they view the Brazilian subnational Courts of Audits (Tribunais de Contas -TCs). The survey was conducted in the context of diagnosis and reform process of the TCs, in the light of the Program of Modernization of External Control of States and Municipalities (Promoex), and points out the issues that affect their administrative perfor mance and institutional legitimacy, as well as their qualities. By interpreting the opinion of the strategic actors intervie wed, the final analysis of this paper seeks to reveal ways to modernize the Courts of Audit at the subnational level.

Rogério Bastos Arantes

Doutor em Ciência Política pela USP e professor da PUC (SP). Contato: rarantes@pucsp.br.

Fernando Luiz Abrucio

Doutor em Ciência Política pela USP, professor do Programa de Mestrado e Doutorado em Administração Pública e Governo da FGV (SP) e professor da PUC (SP). Contato: fabrucio@fgvsp.br.

\section{Marco Antonio Carvalho Teixeira}

Doutor em Ciência Política pela PUC (SP), pesquisador do Programa Gestão Pública e Cidadania da FGV (SP) e professor da Fundação Santo André. Contato: marcoteixeira@fgrvp.br. 


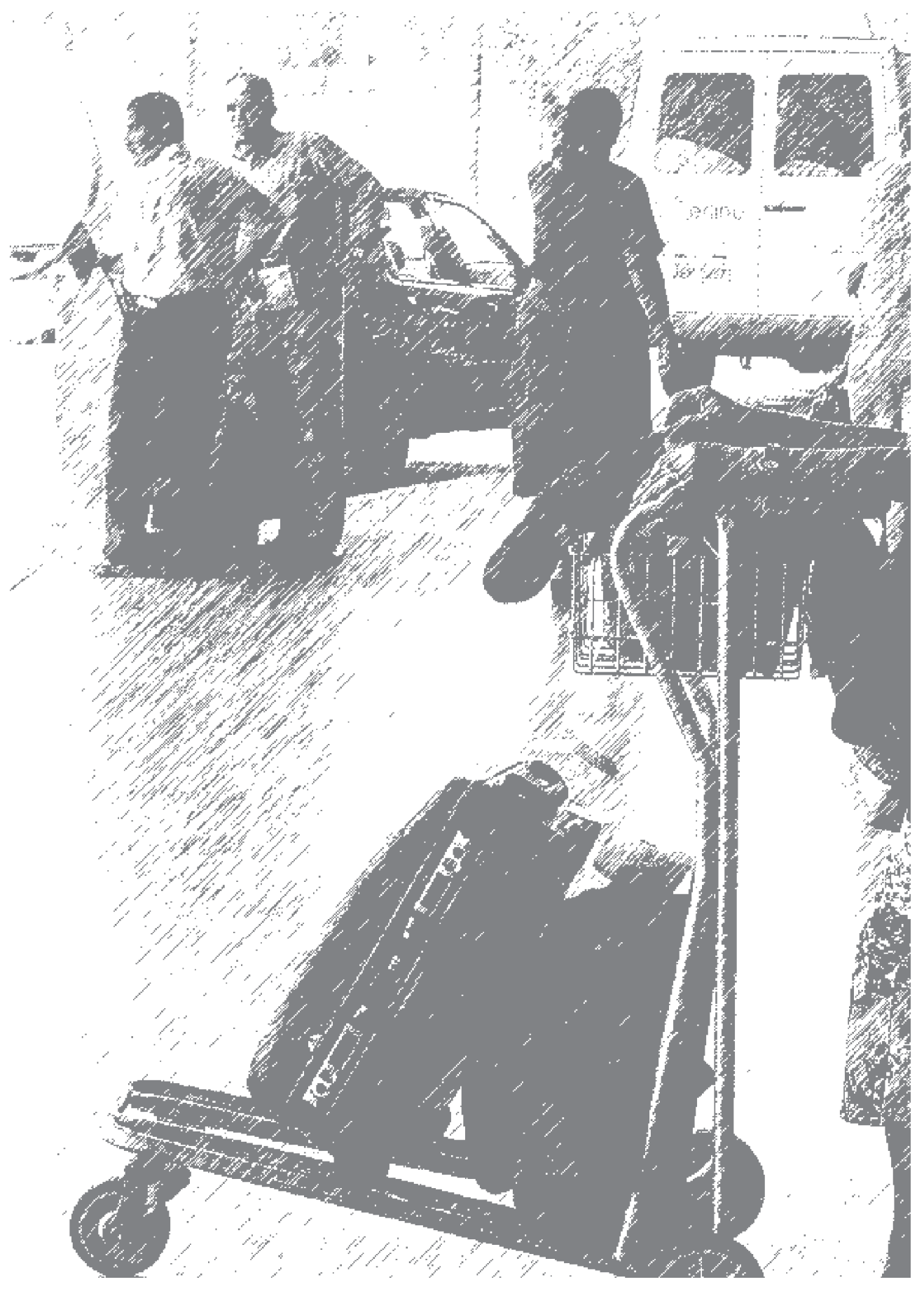

